SUPPLIER Alliances: DiffEREnCES In ATtTITUDES to SUPPLIER AND QUALITY MANAGEMENT OF ADOPTERS AND NON-ADOPTERS

\author{
Vijay R. Kannan \\ Department of Business Administration \\ Utah State University \\ Logan, UT 84322-3510 \\ Tel/Fax: (435) $7977212 / 2634$ \\ Email: v.kannan@usu.edu \\ Keah Choon Tan \\ Department of Management \\ University of Nevada, Las Vegas \\ Las Vegas, NV 89154-6009 \\ Tel/Fax: (702) 895-3873/4370 \\ Email: kctan@unlv.edu
}

June 20, 2003 


\title{
SUPPlier Alliances: Differences in AtTItUdes to SUPPLIER AND QUALITy MANAGEMENT OF ADOPTERS AND NON-ADOPTERS
}

\begin{abstract}
Faced with increasing pressure to improve responsiveness to rapidly changing market needs, firms must respond to the challenge of how to improve supply reliability and quality, while simultaneously reducing costs. For many, this has led to an increase in outsourcing and the adoption of supplier alliances with key suppliers. While much has been written about when and how to form such alliances and the benefits of doing so, little evidence exists of how alliance adopters differ from non-adopters in their attitudes towards managing suppliers and their efforts to manage quality in the supply process. This study presents results of a survey of supply management professionals that examines attitudes of adopters and non-adopters of supplier alliances to supplier and quality management. Results indicate that significant differences in attitudes exist between alliance adopters and non adopters, and that differences have a direct and significant impact on key measures of a buying firm's business performance. The implication for supply managers is that viewing suppliers as an extension of their own organization and identifying those with the desire and motivation to partner with them can have a direct and positive effect on their own firm's performance.
\end{abstract}

\section{Introduction}

Supplier alliances have in recent years become increasingly important to both buyers and suppliers striving to respond to heightened competitive pressures. They reflect recognition by alliance partners that a cooperative relationship may facilitate achieving mutual competitive advantage. Buyer interest in alliances is typically driven by efforts to reduce price, increase the dependability of supply, and influence supplier quality and delivery schedules (Ellram, 1995, Stuart, 1993). Companies seeking to streamline their supply base and/or develop closer ties with suppliers may also, for certain purchases, determine that an alliance is preferable to arms length relationships. Suppliers find alliances attractive since they offer the advantages of a stable, reliable market, and allow them to influence customer quality. Much has been written about the implementation of alliances. Alliances are for example appropriate when 
the item to be purchased is strategically important, and when the buyer and supplier already have a longstanding relationship (e.g., Hendrick and Ellram, 1993, Kapoor and Gupta, 1997). While most alliances are structured formally, as many as a third of all alliances may be informal in nature (Fram, 1995). The commitment required to develop and sustain alliances does however mean that they typically involve less than one percent of a buyer's supplier base (Hendrick and Ellram, 1993), and having fewer than ten partners is not uncommon (Vollmann and Cordon, 1998). Given the impact a partner can have on alliance success, partner selection is important (e.g., McCutcheon and Stuart, 2000, Monczka and Trent, 1995, Monczka et al., 1998). Quality, cost, product/process technology, capability, as well as less quantifiable criteria such as the size, relative power, and financial stability of the supplier, as well as the cultural and strategic fit with the buyer are among criteria that should be considered in partner selection (e.g., Ellram, 1990, McCutcheon and Stuart, 2000, Monczka et al, 1998, Vollmann and Cordon, 1998).

Several studies have also examined the drivers of alliance success and the implications for performance. Top management support, shared goals, trust, open communication, and a commitment to sharing information, continuous improvement, joint problem solving, and responding rapidly to failures to meet expectations, have all been identified as drivers of alliance success (e.g., Ellram, 1991, Landeros et al., 1995, Monczka et al., 1998, McCutcheon and Stuart, 2000, Stuart, 1993, Vollmann and Cordon, 1998, Whipple and Frankel, 2000, Zaheer et al., 2000). Success can manifest itself in terms of improved product availability, customer satisfaction, responsiveness to customer needs, and delivery performance, and lower cost (e.g., Groves and Valsamakis, 1998, Scannell et al., 2000, Stank et al., 1999, Stank et al., 2001). Potential benefits also exist in terms of access to and transfer of technology, and product development (Fram, 1995, Grant and Baden-Fuller, 1995, Heide and John, 1990, Singh, 1997).

While the literature on supplier alliances is extensive, one aspect of alliances that has not been examined is whether firms pursuing alliances are somehow different from those that do not. For example, are attitudes of adopters of alliances towards supply management different from those that do not, or are any differences between firms attributable to how they design and implement supply management strategies. Examining differences between adopters and non-adopters of supplier alliances is important since it provides additional insight into how supply management can impact firm performance. This article presents results of a survey that examines whether firms pursuing alliances differ in their attitudes 
towards supplier and supplier quality management from those that do not, and how any such differences impact product and sales performance.

\section{Research Questions AND Method}

Recent studies have highlighted the importance of links between the supplier management dimensions of supplier selection and assessment, and performance (e.g., Carr and Pearson, 1999, Kannan and Tan, 2002, Vonderembse and Tracey, 1999). Most analyses of supplier selection and assessment, both generally and with respect to supplier alliances, have focused on cost, quality and delivery performance ${ }^{1}$. While prior studies have examined supplier selection and assessment over a range of purchase and product conditions, there is little evidence as to whether the buyer-supplier relationship affects buyer perceptions of the importance of selection and assessment criteria. Although one study examined this issue with respect to the location of the buyer in the supply chain (Choi and Hartley, 1996), it has not been examined in the context of supplier alliances. By virtue of their motivation and commitment to working closely with suppliers to ensure their needs are met, it can be implied that alliance adopters view supplier cost, quality, and delivery performance as being of particular importance. However, whether they view these, and in particular efforts by the supplier to maintain high levels of quality, as being more important than do non adopters is not clear. The same can be said for more qualitative, hard to quantify selection and assessment criteria. It has been shown that criteria such as the overall commitment of a supplier to meeting changing buyer needs may have as great if not a greater impact on the buying firm's performance than measurable criteria such as delivery and service quality (Kannan and Tan, 2002). Indeed, the importance of "soft", difficult to quantity supplier selection criteria was specifically raised with reference to strategic buyer-supplier partnerships (Ellram, 1990). For example, buyer-supplier compatibility, and supplier capability and business history were suggested to be of particular importance. In the context of alliances in which there is significant reliance on suppliers as well as commitment to working collaboratively to seek mutual advantage, "soft" criteria, which might not otherwise be viewed as being important, would seem to be particularly significant. If differences do exist in attitudes towards supplier and quality management between adopters and non adopters of alliances, this raises the question of what the impact of these differences is. As indicated earlier, buyers are

\footnotetext{
${ }^{1}$ A review of the supplier selection and assessment literature can be found in Kannan and Tan, 2002.
} 
motivated to engage in alliances primarily to improve material cost, quality, and delivery. This should in turn enable them to improve their ability to respond to market pressures, and to do so in a manner that gives them a competitive edge over non alliance adopters. Whether this is in fact borne out has not however been assessed.

In summary, four questions as yet unanswered by the supplier alliance literature are examined in this study:

- Do alliance adopters consider measurable supplier selection and assessment criteria to be more important than do non adopters?

- Do alliance adopters consider "soft" supplier selection and assessment criteria to be more important than non adopters?

- Do alliance adopters consider steps taken by suppliers to ensure product quality to be more important than do non adopters?

- Do differences in attitudes towards supplier and quality management have an impact on the buying firm's performance?

To answer these questions, a survey instrument was developed that asked respondents to indicate using five-point Likert scales ( 1 = very unimportant, 5 = very important)

- the importance of eighteen criteria used to select key suppliers

- the importance of nine criteria used to assess the performance of key suppliers

- the importance of fourteen criteria used to assure supplier products conform to specifications

Respondents were also asked to assess their organization's product quality, market share, and competitiveness relative to major competitors using a five-point scale $(1=$ low, $5=$ high). Items used in the survey were identified from the pertinent purchasing literature, company policy manuals, and discussions with supply management professionals. After pre-testing, the survey was sent to materials and purchasing managers in the U.S. and Europe identified from American Production and Inventory Control Society (APICS) and Institute for Supply Management (ISM) membership lists. Five hundred and twenty seven surveys, or ten percent of the surveys mailed, were returned. Of these, approximately forty eight percent came from final product manufacturers and fifteen percent from raw material and component manufacturers. Responding firms varied in size from ten to two hundred thousand employees (median $=250$ ), and had annual sales of between $\$ 20,000$ and $\$ 30$ billion (median $=\$ 30$ million). Of the five hundred and twenty seven responses, two hundred and seventy nine $(52.9 \%)$ indicated the use of supplier alliances, thus the sample was balanced between adopters and non-adopters. 


\section{SURVEY RESULTS}

\section{Attitudinal Differences}

Both adopters and non-adopters of alliances consider on time delivery and commitment to quality to be the most important supplier selection criteria followed by technical expertise (Table 1). Similarly, both consider cultural match between the buyer and seller to be the least important. While the rankings of supplier selection criteria are similar for alliance adopters and non-adopters, minor differences exist. For example, the ability of suppliers to respond to unexpected demand, commitment to continuous improvement, and the strategic importance of the supplier to the buying firm rank as the $4^{\text {th }}, 6^{\text {th }}$, and $10^{\text {th }}$ most important selection criteria respectively to alliance adopters. For non-adopters however, these ranks are $6^{\text {th }}, 9^{\text {th }}$, and $13^{\text {th }}$ respectively. It is interesting to note that even for alliance adopters, selection criteria of a more strategic nature are considered less important than those of a more operational nature. For example willingness to share confidential information and supplier efforts to promote JIT principles and eliminate waste, rank as only the $14^{\text {th }}, 15^{\text {th }}$, and $16^{\text {th }}$ most important criteria respectively for alliance adopters. Of greater significance however is that with few exceptions, differences in importance between adopters and non-adopters of alliances are statistically significant.

\begin{tabular}{|c|c|c|c|c|}
\hline Supplier Selection Criteria ${ }^{1}$ & Adopters $^{2}$ & $\begin{array}{c}\text { Non- } \\
\text { Adopters }^{2}\end{array}$ & $\begin{array}{c}\text { Mean } \\
\text { Difference }^{3}\end{array}$ & $\mathrm{t}$ value \\
\hline Geographical compatibility/proximity & $3.11^{(17)}$ & $2.98^{(16)}$ & 0.13 & 1.29 \\
\hline Industry knowledge & $4.11^{(7)}$ & $4.00(5)$ & 0.11 & 1.33 \\
\hline Ability to meet delivery due dates & $4.63^{(2)}$ & $4.51^{(1)}$ & 0.12 & 1.84 \\
\hline Price & $4.19^{(5)}$ & $4.03^{(4)}$ & 0.16 & 1.89 \\
\hline Technical expertise & $4.32^{(3)}$ & 4.14 (3) & 0.18 & $2.35^{\star}$ \\
\hline Scope of resources & $3.72^{(12)}$ & $3.52(11)$ & 0.20 & $2.47^{\star}$ \\
\hline Past and current relationship with supplier & $3.70^{(13)}$ & $3.48^{(12)}$ & 0.22 & $2.62^{*}$ \\
\hline Testing capability & $3.82(11)$ & $3.57^{(10)}$ & 0.25 & $2.71^{*}$ \\
\hline Commitment to quality & $4.67^{(1)}$ & $4.42^{(2)}$ & 0.25 & $3.41^{*}$ \\
\hline Process capability & $4.09^{(9)}$ & $3.76^{(7)}$ & 0.33 & $3.57^{\star}$ \\
\hline Cultural match between the companies & $3.05^{(18)}$ & $2.67^{(18)}$ & 0.38 & $3.64^{*}$ \\
\hline Efforts to eliminate waste & $3.43^{(16)}$ & $3.02(15)$ & 0.41 & $4.14^{*}$ \\
\hline Willingness to share confidential information & $3.53^{(14)}$ & $3.11^{(14)}$ & 0.42 & $4.51^{*}$ \\
\hline Financial stability and staying power & $4.11^{(7)}$ & $3.71^{(8)}$ & 0.40 & $4.80^{*}$ \\
\hline Commitment to continuous improvement & $4.15^{(6)}$ & $3.68^{(9)}$ & 0.47 & $4.84^{*}$ \\
\hline Ability to respond to unexpected demand & $4.24^{(4)}$ & $3.78^{(6)}$ & 0.46 & $5.13^{*}$ \\
\hline Efforts to promote JIT principles & $3.49^{(15)}$ & $2.90^{(17)}$ & 0.59 & $5.66^{*}$ \\
\hline Strategic importance of supplier to your firm & $4.00^{(10)}$ & $3.41^{(13)}$ & 0.59 & $6.64^{*}$ \\
\hline
\end{tabular}

Table 1. Relative Importance of Supplier Selection Criteria 
Two particular observations can be made regarding comparisons of mean responses. First, not only do alliance adopters consider selection criteria reflecting the strategic importance of the supply chain to be more important than non-adopters as might be expected, they also consider several criteria that are more operational in nature to be more important. For example, it is not surprising that alliance adopters consider the strategic importance of suppliers to the buyer to be more important in selecting suppliers than do non-adopters. However, selection criteria such as technical expertise and scope of resources which one would expect all buyers to consider important, are also considered to be of greater importance to alliance adopters. Second, as one might expect, selection criteria where there is the greatest differential in importance between alliance adopters and non-adopters (based on t statistic values) are those that reflect a strategic commitment to the supply chain. For example, strategic importance of the supplier, supplier efforts to promote JIT principles, and commitment to continuous improvement, are among the selection criteria where there is the greatest difference in importance between alliance and non-alliance adopters. Indeed, it can be seen that all selection criteria with t values in excess of four are more strategic in nature. In contrast, with the exception of commitment to quality, all criteria with $\mathrm{t}$ values less than four are of a more operational nature. It is also worth noting that of the four selection criteria where there is no statistical difference between alliance and non-alliance adopters, two, price and ability to meet due dates, are among the most important for both groups.

Rankings of supplier assessment criteria are identical for both alliance adopters and nonadopters (Table 2). Both groups consider quality, service, and on time delivery to be the most important assessment criteria while willingness to share information and to participate in new product development are considered to be the least important. With the exception of quality level, alliance adopters place greater importance on all assessment criteria. As was the case for supplier selection criteria, the greatest differences between alliance adopters and non-adopters are for assessment criteria that are strategic in nature, for example willingness to participate in new product development activities, share sensitive information, and change products to meet changing needs. These criteria are however, again deemed by both groups to be the least important.

Rankings of supplier conformance criteria are again similar for both alliance adopters and nonadopters (Table 3). Compliance with buyer requirements, conformance of buyer purchased materials with 


\begin{tabular}{lcccc}
\hline \multicolumn{1}{c}{ Assessment Criteria $^{1}$} & Adopters $^{2}$ & $\begin{array}{c}\text { Non- } \\
\text { Adopters }\end{array}$ & $\begin{array}{c}\text { Mean } \\
\text { Difference }\end{array}$ & t value \\
\hline Quality level & $4.70^{(1)}$ & $4.65^{(1)}$ & 0.05 & 0.87 \\
Service level & $4.60^{(2)}$ & $4.46^{(2)}$ & 0.15 & $2.18^{*}$ \\
On-time delivery & $4.57^{(3)}$ & $4.41^{(3)}$ & 0.17 & $2.45^{*}$ \\
Price & $4.15^{(6)}$ & $3.94^{(6)}$ & 0.22 & $2.68^{*}$ \\
Quick response to emergency, problem, special request & $4.53^{(4)}$ & $4.29^{(4)}$ & 0.24 & $3.50^{*}$ \\
Flexibility to respond to unexpected demand changes & $4.38^{(5)}$ & $4.08^{(5)}$ & 0.30 & $3.96^{*}$ \\
Willingness to change products/services to meet changing needs & $4.04^{(7)}$ & $3.67^{(7)}$ & 0.37 & $4.23^{*}$ \\
Willingness to share sensitive information & $3.28^{(9)}$ & $2.86^{(9)}$ & 0.42 & $4.30^{*}$ \\
Willingness to participate in new product development & $3.84^{(8)}$ & $3.14^{(8)}$ & 0.70 & $6.82^{*}$ \\
\hline \multicolumn{2}{r}{ 1 }
\end{tabular}

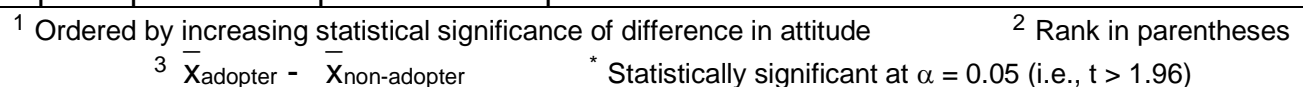

Table 2. Relative Importance of Supplier Assessment Criteria

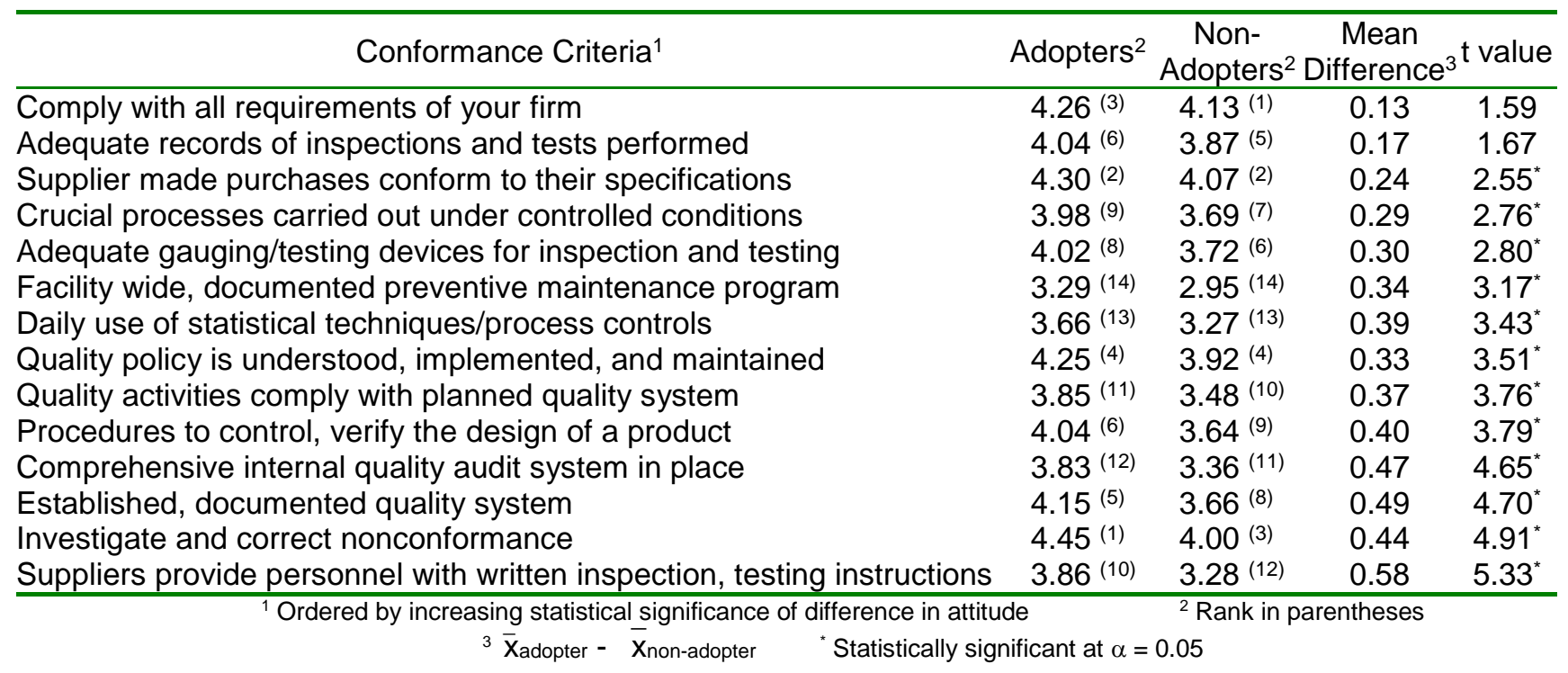

Table 3: Relative Importance of Supplier Product Conformance Criteria

their specifications, investigation of non-conformance, and establishment and implementation of a quality policy are the most important criteria for both groups. Similarly, the existence of a documented preventive maintenance program, daily use of statistical techniques, provision to personnel of written inspection/testing instructions, and the existence of a comprehensive internal quality audit system are in both cases the least important criteria. The only differences in rankings of note are that alliance adopters consider three criteria that correspond to efforts to build quality into processes, investigation/correction of non-conformance, the presence of an established, documented quality system, and procedures to control and verify product designs, to be relatively more important than non-adopters. Once again, with few 
exceptions, alliance adopters place greater importance on individual criteria than non-adopters. It is noticeable that criteria for which there is the greatest difference in importance are in general indicative of the presence of a strategic commitment to quality, for example having an established quality system, internal quality audit system, procedures for controlling quality in product design, and quality policy that is understood, implemented, and conformed with.

\section{Attitudes and Performance}

To identify the extent to which differences in attitudes of adopters and non-adopters of supplier alliance help to explain differences in performance, bivariate correlation analysis was carried out. For each of the three areas of interest, supplier selection, assessment, and product conformance, correlation analysis was carried out for each criterion for which there was a statistically significant difference in mean importance between adopters and non-adopters, and each of the three measures of performance. For six of the fourteen remaining supplier selection criteria, significant positive correlation exists between the criteria and market share performance for alliance adopters firms but not for non-adopters (Table 4). Four of these, waste elimination efforts, commitment to continuous improvement, cultural match between the companies, and strategic importance of the supplier to the buyer, reflect a desire on the part of the buyer to identify suppliers who are committed to improving operations performance and have the potential to be good long term suppliers. Similar results are evident for product quality and competitive position. All selection criteria correlate with product quality performance for alliance adopters whereas the same is true of only seven criteria for non-adopters. For competitive position, eleven criteria correlate positively for alliance adopters but only four for non-adopters. It should be noted that three criteria, process capability, cultural match between the companies, and effort in eliminating waste, have a differential impact on performance (i.e., positive correlation for alliance adopters but not for non-adopters) for all performance measures. In addition, willingness to share sensitive information and testing capability, both have a differential impact on two performance measures. It is apparent from these last two results that criteria indicative of a commitment on the part of a supplier to being a good partner, correlate with performance for alliance adopters, but not for non-adopters, who do not consider these criteria to be as important as alliance adopters. Only one criterion, ability to respond to unexpected demand does not yield any differential impact on performance. 


\begin{tabular}{|c|c|c|c|c|c|c|}
\hline \multirow{2}{*}{ Supplier Selection Criteria ${ }^{1}$} & \multicolumn{2}{|c|}{ Market Share } & \multicolumn{2}{|c|}{ Product Quality } & \multicolumn{2}{|c|}{$\begin{array}{c}\text { Competitive } \\
\text { Position }\end{array}$} \\
\hline & $\begin{array}{c}\text { Non- } \\
\text { Adopters }\end{array}$ & Adc & $\begin{array}{c}\text { Non- } \\
\text { Adopters }\end{array}$ & Ad & $\begin{array}{c}\text { Non- } \\
\text { Adopters }\end{array}$ & Adopters \\
\hline Technical expertise & -.028 & .103 & $.162^{*}$ & $.200^{*}$ & .088 & $.188^{*}$ \\
\hline Scope of resources & .066 & .108 & .127 & $.275^{*}$ & $.160^{*}$ & $.221^{*}$ \\
\hline Past and current relationship with supplier & -.003 & .118 & .103 & $.195^{*}$ & .076 & .117 \\
\hline Testing capability & .026 & $.185^{*}$ & $.191^{*}$ & $.246^{\star}$ & .136 & $.211^{*}$ \\
\hline Commitment to quality & .040 & .030 & $.208^{*}$ & $.276^{\star}$ & .101 & $.166^{*}$ \\
\hline Process capability & .013 & $.253^{\star}$ & .130 & $.269^{*}$ & .108 & $.148^{\star}$ \\
\hline Cultural match between the companies & -.003 & $.128^{*}$ & .017 & $.171^{*}$ & .010 & $.134^{*}$ \\
\hline Efforts to eliminate waste & -.038 & $.136^{\star}$ & .133 & $.210^{*}$ & .068 & $.123^{*}$ \\
\hline Willingness to share confidential information & .003 & $.130^{*}$ & .116 & $.199^{*}$ & .098 & $.156^{\star}$ \\
\hline Financial stability and staying power & .012 & .068 & $.140^{*}$ & $.224^{*}$ & .133 & $.189^{*}$ \\
\hline Commitment to continuous improvement & .084 & $.129^{*}$ & $.235^{*}$ & $.213^{*}$ & $.188^{*}$ & $.134^{*}$ \\
\hline Ability to respond to unexpected demand & .042 & .068 & $.164^{\star}$ & $.200^{*}$ & $.142^{*}$ & $.177^{\star}$ \\
\hline Efforts to promote JIT principles & -.027 & .114 & .117 & $.179^{*}$ & .068 & .090 \\
\hline Strategic importance of supplier to your firm & -.022 & $.126^{*}$ & $.148^{*}$ & $.167^{*}$ & .113 & .098 \\
\hline
\end{tabular}

Table 4. Correlation Analysis: Supplier Selection

Similar observations can be made regarding supplier assessment criteria. While there is only limited evidence of a relationship between assessment criteria and market share and competitive position for either group of firms, there is more evidence when it comes to product quality (Table 5). Participation in new product development activities consistently correlates positively with all measures of performance for alliance adopters but not at all for non-adopters, suggesting its critical role in alliances aimed at enhancing competitive advantage. For two additional criteria, on time delivery and sharing of sensitive information, there is a differential impact on two performance measures. The results also indicate that for alliance adopters, eight of the nine criteria positively correlate with product quality, but only three do so for non-adopters. An unexpected result is that two supplier assessment criteria correlate positively with performance for non-adopters but not for adopters. These include flexibility to respond to unexpected demand changes and the sharing of sensitive information, and competitive position.

Results for supplier product conformance indicate that there is consistent positive correlation of criteria with product quality performance for both alliance adopters and non-adopters (Table 6). There is only limited evidence however of correlation between criteria and market share performance for either group. Only two criteria, daily use of statistical techniques/process controls and procedures to control and 


\begin{tabular}{|c|c|c|c|c|c|c|}
\hline \multirow{2}{*}{ Supplier Assessment Criteria ${ }^{1}$} & \multicolumn{2}{|c|}{ Market Share } & \multicolumn{2}{|c|}{ Product Quality } & \multicolumn{2}{|c|}{$\begin{array}{c}\text { Competitive } \\
\text { Position }\end{array}$} \\
\hline & $\begin{array}{c}\text { Non- } \\
\text { Adopters }\end{array}$ & & $\begin{array}{c}\text { Non- } \\
\text { Adopters }\end{array}$ & Add & $\begin{array}{c}\text { Non- } \\
\text { Adopters }\end{array}$ & Adopters \\
\hline Service level & .103 & -.010 & $.164^{*}$ & $.192^{*}$ & .068 & .116 \\
\hline On time delivery & .043 & .082 & .079 & $.209^{*}$ & .059 & $.156^{*}$ \\
\hline Price & -.001 & .079 & .050 & .013 & .085 & .093 \\
\hline Quick response to emergency, problem, special request & -.037 & .025 & .065 & $.160^{*}$ & -.006 & .088 \\
\hline Flexibility to respond to unexpected demand changes & .055 & -.005 & $.254^{*}$ & $.146^{*}$ & $.150^{*}$ & .057 \\
\hline Willingness to change products/services to meet changing needs & -.039 & .083 & $.147^{\star}$ & $.173^{*}$ & .000 & .102 \\
\hline Willingness to share sensitive information & .030 & $.146^{*}$ & 126 & $.137^{*}$ & $.153^{*}$ & .065 \\
\hline Willingness to participate in new product development & .019 & $.121^{\star}$ & .128 & $.163^{*}$ & .120 & $.142^{*}$ \\
\hline
\end{tabular}

${ }^{1}$ Ordered by increasing statistical significance of difference in attitude * Statistically significant at $\alpha=0.05$

Table 5. Correlation Analysis: Supplier Assessment

\begin{tabular}{|c|c|c|c|c|c|c|}
\hline \multirow[b]{2}{*}{ Supplier Product Conformance Criteria } & \multicolumn{2}{|c|}{ Market Share } & \multicolumn{2}{|c|}{ Product Quality } & \multicolumn{2}{|c|}{ Competitive Position } \\
\hline & $\begin{array}{c}\text { Non- } \\
\text { Adopters }\end{array}$ & $A d$ & $\begin{array}{c}\text { Non- } \\
\text { Sdopters }\end{array}$ & & $\begin{array}{c}\text { Non- } \\
\text { Adopters }\end{array}$ & Adopters \\
\hline Supplier made purchases conform to their specifications & .036 & .002 & $.351^{*}$ & $.184^{*}$ & $.157^{*}$ & .047 \\
\hline Crucial processes carried out under controlled conditions & .046 & .106 & $.295^{\star}$ & $.227^{*}$ & .110 & .097 \\
\hline Adequate gauging/testing devices for testing and inspection & .123 & .080 & $.314^{\star}$ & $.334^{\star}$ & .126 & $.157^{*}$ \\
\hline Facility wide documented preventive maintenance program & .098 & .080 & .056 & $.297^{*}$ & .091 & $.148^{*}$ \\
\hline Daily use of statistical techniques/process controls & .015 & $.138^{\star}$ & $.146^{\star}$ & $.226^{*}$ & .028 & $.159^{*}$ \\
\hline Quality policy is understood, implemented and maintained & 017 & .048 & $.198^{\star}$ & $.273^{*}$ & .042 & $.180^{*}$ \\
\hline Quality activities comply with planned quality system & .063 & .030 & $.257^{*}$ & $.261^{\star}$ & .092 & $.136^{*}$ \\
\hline Procedures to control, verify design of product & .006 & $.173^{\star}$ & $.160^{\star}$ & $.269^{*}$ & .115 & $.170^{*}$ \\
\hline Comprehensive internal quality audit system in place & .024 & .082 & $.248^{*}$ & $.306^{*}$ & .053 & $.162^{*}$ \\
\hline Established, documented quality system & .080 & .091 & $.254^{\star}$ & $.225^{*}$ & .065 & .095 \\
\hline Investigate and correct non conformance & -.024 & .110 & $.251^{*}$ & $.226^{*}$ & .008 & $.183^{*}$ \\
\hline Provide personnel with written inspection, testing ins & .012 & .018 & $.209^{*}$ & $.288^{*}$ & -.003 & $.203^{*}$ \\
\hline
\end{tabular}

${ }^{1}$ Ordered by increasing statistical significance of difference in attitude

* Statistically significant at $\alpha=0.05$

Table 6. Correlation Analysis: Supplier Product Conformance

verify product designs correlate for alliance adopters but none for non-adopters. In contrast, almost all criteria correlate with competitiveness for alliance adopters but not for non-adopters.

\section{IMPLICATIONS}

Several conclusions can be drawn from the results of the survey. First, adopters of supplier alliances consistently place greater importance on supplier selection and assessment criteria than do non-adopters. Not only is this true for soft criteria reflective of a commitment to operations excellence and to lasting relationships with suppliers, but also for more measurable criteria that could equally apply to 
commodity purchases as they could to more strategically significant purchases. Second, alliance adopters attach greater importance than non-adopters to ensuring that suppliers have taken steps to ensure high levels of product quality. Not only are they more concerned about whether suppliers' have a system for quality in place, but they are also place more importance on how everyday quality tasks are carried out. These differences in attitudes are significant since they indicate that if attitude influences action, the effectiveness of procurement and quality strategies may be compromised by a failure to treat elements of the strategies with due consideration. One can speculate that firms that view the contribution of suppliers to their own performance critically may be more effective in their implementation of a given procurement strategy, or may develop more effective strategies than those who do not. Third, the results suggest that differences in attitudes do impact performance. The results are particularly significant in demonstrating a link between differences in attitudes and competitiveness. This is consistent with the use of alliances as a means of enhancing long-term product performance. While not as conclusive, the results also indicate a potential link between differences in attitudes and market share performance. Fewer of the criteria examined correlate with market share performance than for competitiveness, but those that do, do so only for alliance adopters. Taken together, the results demonstrate the impact of attitudes to supply management on performance. Viewing suppliers as an extension of one's own organization and identifying those with the desire and motivation to be partners not just suppliers, is an important driver of one's own success.

The results here also suggest areas for further study. Differences in attitudes of alliance adopters and non-adopters leads to the question of how attitudinal differences are reflected in the development, implementation, and impact of supply and quality management strategies. In other words do these differences result in fundamentally different strategies being shaped or are performance differences between alliance adopters and non-adopters the result of differences in implementation. If it is the latter, this raises the question how is implementation impacted by attitude. A related question is do supply and quality management strategies in fact reflect the attitudes of supply management professionals or are they driven by broader strategic variables. While in a broader purchasing context it has been shown that a disconnect sometimes exists between the perceived importance of supplier selection criteria and practice, the results here raise the possibility that consistency between attitudes and practice may be one factor in 
explaining the differential impact of supply and quality management of those that do and don't adopt supplier alliances.

\section{References}

1. Carr, A.S., and Pearson, J.N., (1999) "Strategically managed buyer-supplier relationships and performance outcomes", Journal of Operations Management, Vol. 17 No. 5, pp. 497-519.

2. Choi, T.Y., and Hartley, J.L., (1996) "An exploration of supplier selection practices across the supply chain", Journal of Operations Management, Vol. 14 No. 4, pp. 333-343.

3. Ellram, L.M. (1990) "The supplier selection decision in strategic partnerships", Journal of Purchasing and Materials Management, Vol. 26 No. 4, pp. 8-14.

4. Ellram, L.M. (1991) "A managerial guideline for the development and implementation of purchasing partnerships", Journal of Purchasing and Materials Management, Vol. 27 No. 3, pp. 2-8.

5. Ellram, L.M. (1995) "Partnering pitfalls and success factors", International Journal of Purchasing and Materials Management, Vol. 31 No. 2, pp. 36-44.

6. Fram, E.H. (1995) "Purchasing partnerships: The buyer's view", Marketing Management, Vol. 4 No. 1, pp. 49-55.

7. Grant, R.M., and Baden-Fuller, C., (1995) A knowledge based theory of inter-firm collaboration", Academy of Management Journal, Best Papers Proceedings, pp. 17-20.

8. Groves, G., and Valsamakis, V., (1998) "Supplier-customer relationships and company performance", International Journal of Logistics Management, Vol. 9 No. 2, pp. 51-64.

9. Heide, J.B., and John, G., (1990) "Alliances in industrial purchasing: The determinants of joint action in buyer-supplier relationships", Journal of Marketing Research, Vol. 27, pp. 24-36.

10. Hendrick, T.E. and Ellram L.M. (1993), Strategic supplier partnerships: An International Study, Center for Advanced Purchasing Studies, Tempe.

11. Kannan, V.R., and Tan, K.C., (2002) "Supplier selection and assessment: Their impact on business performance", Journal of Supply Chain Management, Vol. 38 No. 4, pp. 11-19.

12. Kapoor, V. and Gupta A. (1997) "Aggressive sourcing: A free market approach", Sloan Management Review, Vol. 39 No. 1, pp. 21-31.

13. Landeros,R., Reck, R., and Plank, R.R. (1995) "Maintaining buyer-supplier partnerships", International Journal of Purchasing and Materials Management, Vol. 31 No. 3, pp. 3-11.

14. McCutcheon, D. and Stuart F.I. (2000) "Issues in the choice of supplier alliance partners", Journal of Operations Management, Vol. 18 No. 3, pp. 279-301.

15. R.M. Monczka, and R.J. Trent, (1995) Purchasing and sourcing strategy: Trends and implications, Tempe: National Association of Purchasing Management/Center for Advanced Purchasing Studies.

16. Monczka, R.M., Peterson, K.J., Handfield, R.B. and Ragatz, G.L. (1998) "Success factors in strategic supplier alliances: The buying company perspective", Decision Sciences, Vol. 29 No. 3, pp. 553-577.

17. Scannell, T.V., Vickery, S.K., and Dröge, C.L., (2000) "Upstream supply chain management and competitive performance the automotive supply industry", Journal of Business Logistics, Vol. 21 No. 1, pp. 23-48.

18. Singh, K., (1997) "The impact of technological complexity and interfirm cooperation on business survival", Academy of Management Journal, Vol. 40, No. 2, pp. 339-367.

19. Spekman, R., (1988) "Strategic supplier selection: Understanding long-term buyer relationships", Business Horizons, Vol. 31 No. 4, pp. 75-81. 
20. Stank, T., Crum, M., and Arango, M., (1999) "Benefits of interfirm coordination in food industry supply chains", Journal of Business Logistics, Vol. 20 No. 2, pp. 21-41.

21. Stank, T., Keller, S.B., and Daugherty, P.J., (2001) "Supply chain collaboration and logistical service performance", Journal of Business Logistics, Vol. 22 No. 1, pp. 29-48.

22. Stuart, F.I. (1993) "Supplier partnerships: Influencing factors and strategic benefits", International Journal of Purchasing and Materials Management, Vol. 29 No 4, pp. 22-28.

23. Vollmann T.E. and Cordon, C. (1998) "Building successful customer - supplier alliances", Long Range Planning, Vol 31 No 5, pp. 684-694.

24. Vonderembse, M.A., and Tracey, M., (1999) "The impact of supplier selection criteria and supplier involvement on manufacturing performance", Journal of Supply Chain Management, Vol. 35 No. 3, pp. 33-39.

25. Whipple, J.M., and Frankel, R., (2000) "Strategic alliance success factors, Journal of Supply Chain Management, Vol. 36 No. 3, pp. 21-28.

26. Zaheer, A., McEvily, B., and Perrone, V. (1998) "The strategic value of buyer-supplier relationships," Journal of Supply Chain Management, Vol. 34 No. 3, pp. 20-26. 